\title{
The Relationship between Passionate Love with Belief in Free Will, Belief in Determinism and Second-Order Volition.
}

\author{
Ezra Putranto Wahyudi ${ }^{1 *}$ and Bagus Takwin ${ }^{2}$ \\ ${ }^{1 .}$ Faculty of Psychology, Universitas Indonesia, Depok, 16424, Indonesia \\ 2. Faculty of Psychology, Universitas Indonesia, Depok, 16424, Indonesia \\ *E-mail: ezra.putranto@ui.ac.id
}

\begin{abstract}
This study has a purpose to understand the effect of passionate love on the belief in free will and determinism and to observe the interaction effect of second-order volition in moderating the relationship between passionate love with belief in free will and belief in determinism. Passionate love in this study is defined as a state of intense longing for union with a significant other that manifests into a complex functional gamut of appraisals or appreciations, subjective feelings, expressions, patterned physiological processes, tendencies, and instrumental behaviors. Instruments that had been used in the study areThe Passionate Love Scale, Free Will and Determinism Scale-PLUS and Second-order Volition Test which constructed by the researchers. This study also has the. Participants of this study were 118 undergraduate students at the Faculty of Psychology of the University of Indonesia. The results found that passionate love has no significant effect on belief in free will and determinism. Data analysis using process macro finds no interaction effect of second-order volition in moderating the relationship of passionate love with belief in free will and belief in determinism.
\end{abstract}

Keywords: Belief in determinism, belief in free will, passionate love, second-order volition.

\section{Introduction}

The discourse on the nature and essence of love have given colors to the experience of being a human in various forms of literature, poetry, novels, and even songs. The great works of philosophers such as Plato, Schopenhauer, Sartre, Nietzsche and Fromm to poets such as Baudelaire and Neruda have given us a fundamental question in seeking for the meaning of the word love: Is love a choice determined by free will in the agency of a human themselves? Or rather, is love a mere mystification of the animal impulses to encourage human beings to continue the survival of their species?

This contradiction not only plagues the musings of poets or philosophers but also in the realms of science as well. Fisher (2014) argues that passionate love can be categorized as an addiction: A positive addiction when love occurs reciprocally can potentially turn into a foundation of intimacy (Hazan \& Diamond, 2000). Passionate love can also turn into a negative addiction if the given love is rejected, considered as inappropriate or unrequited which will potentially lead into depression, suicidal thoughts, and even murder (Meloy, 1998; Meloy \& Fisher, 2005). Data obtained using fMRI machine shows that intense romantic feelings are associated with areas of the brain that regulate dopamine intake-more specifically dopamine pathway involved in energy regulation, focus, motivation, and excessive desire. These also include areas of the brain which are activated when an individual is addicted to opioids (Bartels \& Zeki, 2000; Fisher et al 2003; Bartels dan Zeki, 2004; Aron et al., 2005; Fisher et al., 2005; Ortigue et al., 2008; Fisher et al., 2010' Acevedo et al., 2011; Xu et al., 2011). Based on these data, it can be concluded that feelings of love have a deterministic nature, in which the individual could not avoid the biological constraints and love itself can be considered an addiction where the individual can lose their self-control which could lead them to so behave dangerously in pursuit of a romantic relationship (Griffin-Shelley 1991; Halpern 1982; Liebowitz 1983; Mellody et al. 1992; 
Peele \& Brodsky 1975; Schaef 1989; Tennov 1979). The results of various studies have shown a strong relationship between passionate love and determinism. Therefore, in this study, determinism can be defined as individual beliefs in which they believe there is a lack of choice, control, and determination beyond their own control in having a romantic relationship.

Meanwhile, Fromm (1956) stated an important factor which left behind in engaging a romantic relationship is will. The act of loving is not only based on feelings or emotion, but rather on a decision, a judgment, and a promise. The empirical results of a study conducted by Feldman, Baumeister, and Wong (2014) reinforce the relationship between passionate love and the belief in free will. An individual facing more choices will increase his belief in free will. In the context of a romantic relationship, an individual feel loved have opened up many various of options in expressing $\mathrm{him} / \mathrm{herself}$ to his/her partner which previously, they have no access to. Alternatively, an individual who thinks about romantic relationship increases their overall positive affect and glucose level in their bloodstream (Stanton, Campbell \& Loving, 2014) which simultaneously increases their level of selfcontrol (Gailliot \& Baumeister, 2007). Given by previous research (Baumeister \& Monroe, 2014) which strongly tied self-control with belief in free will. Therefore, the evidence provided from these studies could explain the strong relationship between passionate love and belief in free will from physiological and cognitive standpoints.

The findings in these $\mathrm{c}$ studies only exacerbate the discourse of the nature of love. Furthermore, a study conducted by Boudesseul, Lantian, Cova, and Bègue (2016) attempted to answer the contradiction of the nature of love. Here, they found a significant correlation between belief in free will and determinism with passionate love. The results of their study are incompatible with both free will and determinism because it shows there is a positive correlation between belief in free will and determinism with passionate love at the same time. In their discussion, Boudesseul et al., (2016) explain that the feeling of passionate love triggers different conceptual associations on the participants depending on their personal experiences.

The correlations of the results in Boudesseul's study could not provide a direction of causality. Therefore, this research aims to do so. Thus, to understand the relationship between passionate love with belief in free will and determinism, the study employs experimental methods. In this research manipulated the state of feelings of love in a participant through inductionmating mindset (Li, Kenrick, Griskevicius, \& Neuberg, 2012). Knowledge about how passionate love affects the belief in free will and determinism will enable researcher evaluated how passionate love (presented through mating-mindset induction) can strengthen the belief in free will and determinism.

In accordance with the inconclusive outcome of his research, Boudesseul et al., (2016) presented a true self approach towards his results which explains when an individual is considered to be free if a behavior comes from their own true self, which is comprised of values and goals which he closely holds (Watson, 1971). Therefore, it did not concern itself with the values or goals of the individual (love comes from inner intentions of the individual) and whether they are made up of external factors (love stems from genetic or educational attributes). Rather, what's more, important is whether or not the individual acts are in accordance with these values and goals. Therefore, it is possible for an individual loved his/her partner as free and determined.

This idea was based on the theory of free will according to Frankfurt (1971) that explained the will of an individual is determined by the complexity of the motivation that compels him to behave a certain way. Frankfurt (1971) coined this construct as second-order volition in which it reflects the will of a man in accordance with his beliefs, preferences or purposes. Hence, the secondorder volition of a man is identified with his own desire and this desire is part of their personal identity. The individual's own belief, preferences or purpose in life will have the potential to discords with their own intention to manifest their passionate love towards his/her partner. This decision to pursue or leaves the desire to manifest the passionate love towards the partner will reflect the individual's second-order volition.

Therefore, this present research is expected to provide an empirical explanation of the interpretation of Boudesseul's research results using a 'true self' approach to free will by using secondorder volition as the moderator variable. This variable is expected to moderate the relationship between passionate love with belief in free will and determinism.

\section{Methods}

Sample. Participants in this study are undergraduate students at the Faculty of Psychology of the 
University of Indonesia. In total, there were 118 participants $(M=19.94, S D=1.14,78.8 \%$ women $)$ varying from different batches. Participants were recruited by using accidental sampling. There are no specific methods to determine a romantic relationship or the quality of the romantic relationship among the participants.

Research Design. This study used an experimental research design where the participants were randomly assigned into two groups: high passionate love (Experiment group) and low passionate love (Control group). Randomization in this research was done through determining the row of seats calculated from the front row of the classroom. Participants sitting on odd row seats are assigned into the experiment group. Meanwhile, participants who sit on even rows) are assigned into the control group. Therefore, this study categorized as experimental between-subject design.

Instrument and Measurement. Passionate love was measured by using self-report method through the Passionate Love Scale (PLS) questionnaire. In previous studies, the PLS had reliability coefficient with alpha 0.91 (Hatfield \& Sprecher, 1986), and the construct validity of PLS proved to be valid when PLS was tested with similar measurement (Sprecher \& Regan, 1998). The reliability test on the PLS measuring instrument was performed during the first pilot study in which the Cronbach Alpha value of 0.949 was obtained. Participants were asked to rate how well each statement describes their own characteristics with 30 statements on a 9-point scale. PLS measures passionate love as a state in how participants feel about the object of the participant's love in which they imagine. Therefore, it can be concluded that instrument is appropriate in this study because the manipulation given in this research is temporary.

In an attempt to measure the second order volition variable, the researchers constructed a new measuring instrument. Second-order volition was measured using self-report method through questionnaires formed by the researchers themselves under the name Second Order Volition Test (SOVT). The formation of SOVT measuring instruments starts from several stages. A preliminary study was conducted on 44 (33 women and 11 men) undergraduate students at the University of Indonesia. The preliminary study was conducted to find out the concrete form of the second-order volition in the view of laymen which falling in love had been put into context as first-order desire and the appropriate reaction of the respondents to the desires that they possess. The definition of the second-order volition and the dynamics of interaction with the first-order desire and the will in the context of falling in love become the categorization of the qualitative. Referring to the definition, an individual with a strong second-order volition has the ability to overcome and regulate his actions against his desire (falling in love). Moreover, an individual with a strong second-order volition has the ability to make coherent decisions with his original self (worth and purpose), without being influenced by his own desires (falling in love). Based on this rationale, the preliminary study obtained three dimensions of the second-order volition: self-control, behavior control and self-consistency. One of the items from SOVT is "I will still love the person I love, even though she does not meet my ideal standards". Participants were asked to rate how well each statement describes their own characteristics with 10 statements on a 6-point scale, SOVT measures participants' desire in having another desire (which have oppositional nature from passionate love) that he wants to make as his will according to his beliefs, preferences or goals in the context of falling in love.

Based on the data obtained from 48 respondents, the researcher conducted an item pooling and obtained 14 items representing each dimension -4 items of the self-control dimension, 6 items of the behavior control dimension, and 4 items of the consistency dimension. Another test was conducted to statistically measure the reliability of SOVT. 181 participants shared the same characteristics with the participants of this study. All data were obtained from the internet. Initially, SOVT garnered the alpha value of 0.643 . After the deletion of 3 items based on the corrected item-total correlation value below 0.2 (Nunnaly \& Bernstein, 1994), an alpha reliability value of 0.713 was thusly determined.

The belief in free will and determinism is measured by using the self-report method through the FADPLUS (Free Will and Determinism Scale-Plus) questionnaire. Dimensions of the FAD-Plus measuring instrument obtained an alpha value of 0.68 to 0.82 in the previous study (Carey and Paulhus, 2013). This instrument obtained an alpha value of 0.674 on the free will dimension. One example of the items from the free will dimension in FAD-Plus is that "people have full control over the decisions they make.". Meanwhile, this instrument has an alpha value of 0.648 on the scientific determinism dimension. One example of the items of the scientific determinism dimension is "Your genes determine your future". Participants were asked to assess their suitability with 8 statements on a 5-point Likert scale. This instrument used a scale that measures these two constructs independently, not a 
polarization. Therefore, the participants have the potential to score high on free will and determinism simultaneously,

Procedure. This research is administered in groups in one of the classrooms at the Faculty of Psychology, University of Indonesia. There are four experimenters involved in this study. Before the study began, each of the experimenters was given detailed information about the research procedure from the opening section, instruction giving, and debriefing section. This was done to facilitate each experimenter having information on what to do when experiments begin and standardized the use of instruction.

Randomization in this research was done through determining the row of seats calculated from the front row of the classroom. Participants sitting on odd row seats are assigned into the experiment group. Meanwhile, participants who sit on even rows are assigned into the control group.

Participants were informed of the nature of this study: that it's a study of imaginative ability and its relationship with creativity. First, each group was presented with a visualization scenario. Each visualization scenario was around 800 words. The manipulation of passionate love will be done through induction of motivational mating (see $\mathrm{Li}$, Kenrick, Griskevicius, \& Neuberg, 2012); mating motivation is induced by guided visualization. Each of the scenarios was read by the participants for 10 minutes. The correlations of the results in Boudesseul's study could not provide a direction of causality. Therefore, this research aims to do so. Thus, to understand the relationship between passionate love with belief in free will and determinism, the study employs experimental methods. So this research aims to manipulate the state of feelings of love in a participant through induction-mating mindset $(\mathrm{Li}$, Kenrick, Griskevicius, \& Neuberg, 2012). By knowing how passionate love affects the belief in free will and determinism, this research can evaluate how passionate love (presented through mating-mindset induction) can strengthen the belief in free will and determinism.

In the experiment group, participants were asked to imagine a date with whom the participants have a crush on. In the scenario, participants imagine spending a day full of romance with his new partner. The meeting ends with a kiss on the participant's forehead. Meanwhile, in the control group, participants were given a scenario with approximately the same number of words, but have no romance or sexual content in the scenario. Participants are asked to imagine to look for an item. At the end of the scenario, the participant succeeds in finding the item and is happy for its success. At the end of each of the scenarios, the experimenter will give a small piece of paper containing three questions to ensure that participants read the whole of the given scenario. If the participant failed to answer two of the three questions then the participant is declared failed, given debriefing paper to be read, and the participants are asked to leave the room. After that, the experimenters will provide three questionnaires, after participants have read the scenario for 10 minutes. Passionate Love Scale (Hatfield \& Sprecher, 1986) will be administered to both research groups as a method of measuring passionate love. Then, the participants were asked to fill in some items on the Second-order Volition Test (SOVT). Next, participants will be given The Free Will and Determinism Scale (FAD-Plus: Paulhus \& Carey, 2011). Next, the experimenter asked the participants in groups about what was measured in this study. Participants are then given debriefing after the entire procedure is completed.

\section{Results}

From the study results shown in table 1, the participants in the experiment group had a significantly higher mean passionate love score than the participants in the control group, $(\mathrm{t})(116)=$ $3.218, \mathrm{p}=0.02)$. Therefore, it proved that mating motivation manipulation can improve passionate love in the participants. This is consistent with the assumption of Boudesseul et al. (2016) in which the induction of motivational mating using a romantic scenario can increase the passionate love of an individual. Even though, the results of the independent sample t-test in table 1 also show that there is no significant difference in mean score in all variables. This shows that there is no influence of high passionate love score to the score of confidence variable to free will $(\mathrm{t}(116)=-0.342, \mathrm{p}>$ 0.05 ) and the result also shows no influence of high passionate love variable score to belief in determinism score $(\mathrm{t}(116)=0.443, \mathrm{p}>0.05)$. Thus, it can be concluded that in this study did not find a causal relationship between passionate love with belief in free will and determinism. 
Table 1.

Results of The Independent Sample t-test

\begin{tabular}{|c|c|c|c|c|c|c|}
\hline $\begin{array}{c}\text { Variab } \\
\text { les }\end{array}$ & $\begin{array}{c}\text { Gro } \\
\text { up }\end{array}$ & $N$ & $M$ & $S D$ & $\begin{array}{c}t \\
- \\
\text { statisti } \\
c s\end{array}$ & $\begin{array}{c}p- \\
\text { valu } \\
e\end{array}$ \\
\hline \multirow{2}{*}{$\begin{array}{c}\text { Passio } \\
\text { nate } \\
\text { Love }\end{array}$} & Exp. & 62 & 106.6 & 13.90 & \multirow{2}{*}{3.218} & \multirow{2}{*}{$\begin{array}{c}\mathrm{p}< \\
0.05\end{array}$} \\
\hline & Con. & 56 & 97.16 & 15.98 & & \\
\hline \multirow{2}{*}{$\begin{array}{c}\text { Second } \\
\text {-order } \\
\text { Volitio } \\
\text { n }\end{array}$} & Exp. & 62 & 33.46 & 5.65 & \multirow[t]{2}{*}{-1.077} & \multirow{2}{*}{$\begin{array}{c}\mathrm{p}> \\
0.05\end{array}$} \\
\hline & Con. & 56 & 34.57 & 5.45 & & \\
\hline \multirow{2}{*}{$\begin{array}{c}\text { Belief } \\
\text { in Free } \\
\text { Will }\end{array}$} & Exp. & 62 & 16.41 & 2.09 & \multirow[t]{2}{*}{-0.342} & \multirow{2}{*}{$\begin{array}{c}\mathrm{p}> \\
0.05\end{array}$} \\
\hline & Con. & 56 & 16.55 & 2.16 & & \\
\hline $\begin{array}{l}\text { Belief } \\
\text { in } \\
\text { Deter }\end{array}$ & Exp. & 62 & 13.40 & 2.13 & \multirow[t]{2}{*}{0.443} & \multirow[t]{2}{*}{$\begin{array}{c}\mathrm{p}> \\
0.05\end{array}$} \\
\hline $\begin{array}{c}\text { minis } \\
\mathbf{m}\end{array}$ & Con. & 56 & 13.23 & 2.05 & & \\
\hline
\end{tabular}

In order to gain the knowledge of the relationship between second-order volition with all the variables, the conditional process model 1 analysis of PROCESS Macro created by Hayes (2013) was used and using bootstrap samples of 5000. Passionate love is included as an independent variable, belief in free will and belief in determinism variables are included as outcomes variable, and second-order volition variable is included as a moderator variable.

Table 2.

The Moderation Effect of Second-order Volition on Belief in Free Will

\begin{tabular}{cccccc}
\hline $\begin{array}{c}\text { Variabl } \\
\text { es }\end{array}$ & $\boldsymbol{B}$ & $\begin{array}{c}\boldsymbol{t} \text { - } \\
\text { statisti } \\
\boldsymbol{c s}\end{array}$ & $\begin{array}{c}\boldsymbol{p} \text { - } \\
\text { value }\end{array}$ & $\begin{array}{c}\text { BootL } \\
\boldsymbol{L C I}\end{array}$ & $\begin{array}{c}\text { Boot } \boldsymbol{L} \\
\boldsymbol{L} \boldsymbol{C I}\end{array}$ \\
\hline $\begin{array}{c}\text { Belief in Free Will } \\
\text { Passion } \\
\text { ate } \\
\text { Love }\end{array}$ & -0.024 & -1.705 & 0.05 & -0.052 & 0.039 \\
$\begin{array}{c}\text { Second- } \\
\text { order } \\
\text { Volition }\end{array}$ & -0.037 & -0.954 & 0.05 & -0.115 & 0.040 \\
PL X & & & $\mathrm{p}>$ & & \\
SOV & 0.002 & 0.0020 & 0.05 & -0.017 & 0.063 \\
\hline
\end{tabular}

$R^{2}=0,0327 ; F=1,285 ; p>0,05$

Based on the results of data processing in table 2, it can be seen that the value of $R^{2}$ equals 0.0327 . This value represents 3.27 percent of the variance of the belief in free will that can be explained through this model with passionate love as an independent variable and a second-order volition as a moderator variable. A value of $R^{2}$ of 0.0327 indicates that the model has no effect on the passionate love variable $(p>0.05)$. Also, results of data processing can be seen a direct relationship between second-order volition as a moderator variable with the belief in free will. The results of the analysis show that there is no significant influence of the passionate love variable $(\mathrm{t}(114)=$ $1.705, \mathrm{p}>0.05)$ on the belief in free will.

Table 3.

The Moderation Effect of Second-order Volition on Belief in Determinism

\begin{tabular}{|c|c|c|c|c|c|}
\hline $\begin{array}{c}\text { Variabl } \\
\text { es }\end{array}$ & $\boldsymbol{B}$ & $\begin{array}{c}t- \\
\text { statisti } \\
c s\end{array}$ & $\begin{array}{c}p- \\
\text { value }\end{array}$ & $\begin{array}{c}\text { BootL } \\
\text { LCI }\end{array}$ & $\begin{array}{c}\text { BootU } \\
\text { LCI }\end{array}$ \\
\hline \multicolumn{6}{|c|}{ Belief in Determinism } \\
\hline $\begin{array}{c}\text { Passion } \\
\text { ate } \\
\text { Love }\end{array}$ & 0.0024 & 0.166 & $\begin{array}{l}\mathrm{p}> \\
0.05\end{array}$ & -0.025 & 0.030 \\
\hline $\begin{array}{l}\text { Second- } \\
\text { order } \\
\text { Volition }\end{array}$ & 0.031 & 0.796 & $\begin{array}{l}\mathrm{p}> \\
0.05\end{array}$ & -0.046 & 0.108 \\
\hline $\begin{array}{l}\text { PL X } \\
\text { SOV }\end{array}$ & 0.001 & 0.002 & $\begin{array}{l}\mathrm{p}> \\
0.05\end{array}$ & -0.002 & 0.005 \\
\hline \multicolumn{6}{|c|}{$R^{2}=0,0391 ; F=1,14 ; p>0,05$} \\
\hline
\end{tabular}

Based on the results of data processing in table 3 , it can be seen that the value of $\mathrm{R}^{2}$ equals 0.0391 . This value represents 3.91 percent variance of belief in determinism which can be explained through this model with passionate love as an independent variable and second-order volition as a moderator variable. The $\mathrm{R}^{2}$ value of 0,0391 indicates that the research model has no effect on the passionate love variable $(p>0,05)$. Also, results of data processing can be seen a direct relationship between second-order volition as a moderator variable with the belief in determinism. The results of the analysis show that there is no significant influence of the passionate love variable $(\mathrm{t}(114)=$ $0.166, p>0.05)$ on the belief in determinism.

\section{Discussion \& Conclusion}

Discussion. The results of Boudesseul's research does not provide a definite conclusion to the relationship between belief in free will and determinism in passionate love. Therefore, he uses a 'true self' approach to free will where an individual is free to behave from within his or her own 'true self' (Watson 1987). The true self of an individual refers to the values and goals that are closely held by the 
individual. Through this explanation, whether love can be classified as the product of the will or determinism does not become an important question to answer, as long as the individual act in accordance with the true self. Therefore, an individual's love for the partner can be free (coming from the original self of the individual) and determined (the true self is formed of the individual factors outside of his control) at the same time. Through this explanation, Boudesseul can explain the inconsistency of his research.

The hypothesis of this study has the objective of falsifying the results of the Boudesseul's research. However, the results of this study found no interaction effects of second-order volition as the moderating variable on passionate love with belief in free will and determinism. This suggests that the interpretation of Boudesseul's research was empirically proven. The evidence provided by this study has found that the dynamics (high or low level) of second-order volition of an individual does not give a significant effect on the participant's belief in free will and determinism. In conclusion, the human ability to have a second-order volition does not determine whether the individual has a belief in free will or determinism. Moreover, the insignificant results confirm the findings of Frankfurt (1987) upon second-order volition with belief in free will and determinism. Frankfurt states that his theory of freedom of will has a neutral position on the problem of determinism and free will. He considers secondorder volition a capability that distinguishes human beings from animals, in which animals could not act on self-control (driven by first-order desire). Humans may still use their will to act, regardless of whether they have certain preternatural assumptions about their beliefs in free will or determinism.

The findings in this experimental study serve as empirical evidence that passionate love does not exert a causal influence on belief in free will or belief in determinism. This indicates that the suggestion of Boudesseul's research was not proven in this sample. He states that there is a potential causal relationship between passionate love for belief in free will and the belief in determinism in which Boudesseul speculates when an individual thinks about a person he loves, some cognitive and emotional components of passionate love can increase the confidence of the individual on the free will or individual belief in determinism.

Conclusions. Based on the results of statistical analysis, this study found no causal relationship between passionate love with belief in free will and did not find any causal relationship between passionate love with belief in determinism. Also, the data analysis results also show that the second-order volition does not moderate the effect of passionate love on belief in free will and determinism.

The insignificant result of this study clarify the dynamics of the relationship between passionate love, belief in free will and determinism which opens another possibility indicating contrary causal direction different from this study. In addition, this study also adds to the body of research in social psychology and experimental philosophy upon the nature of beliefs in free will-determinism, and how these beliefs have the potential to influence the actions of individuals in daily living, especially in an interpersonal relationship.

There are some limitations in this study which have the potential to impact the obtained results, such as there are no specific controls on the participant's relationship (single or in a relationship) and the quality of the relationship itself. Also, belief in free will and determinism could be classified as a trait of the participants which difficult to be changed with induction of mating motivation.

Further research in this study should change the direction of causality of the variables in which the two variables became the independent variables and passionate love served as the dependent one. This framework derived from the perspective of developmental psychology in which both beliefs are based upon a concept of agency, and the ability in distinguishing deliberate and accidental actions. These abilities are observed in the early stages of human development that may first arise compared to all forms of passionate love. One of the examples of this ability is in the form of a child under one year have an expectation of an agent to change the direction of the agent's hand if blocked by a barrier (Phillips and Wellman, 2005). Therefore, it can be said the relationship of belief in free will and determinism in adults can be a complex form of a simple phenomenon which already exists since childhood.

\section{References}

Bartels, A., \& Zeki, S. (2000). The neural basis of romantic love. Neuroreport, 11(17), 3829-3834.

Bartels, A., \& Zeki, S. (2004). The neural correlates of maternal and romantic love. Neuroimage, 21(3), 1155-1166.

Baumeister, R. F., \& Monroe, A. E. (2014). Recent research on free will: Conceptualizations, beliefs, and processes. Advances in Experimental Social Psychology, 50, 1-52. 
Boudesseul, J., Lantian, A., Cova, F., \& Bègue, L. (2016). Free love? On the relation between belief in free will, determinism, and passionate love. Consciousness and Cognition, 46, 47-59. doi:10.1016/j.concog.2016.09.003

Bullis, C., Clark, C., \& Sline, R. (1993). From passion to commitment: Turning points in romantic relationships. Interpersonal communication: Evolving interpersonal relationships, 213-236.

Carey, J. M., \& Paulhus, D. L. (2013). Worldview implications of believing in free will and/or determinism: Politics, morality, and punitiveness. Journal of Personality, 81(2), 130-141.

Feldman, G., Baumeister, R. F., \& Wong, K. F. E. (2014). Free will is about choosing: The link between choice and the belief in free will. Journal of Experimental Social Psychology, 55, 239-245.

Fisher, H.E. (2004). Why we love: the nature and chemistry of romantic love. Macmillan.

Fisher, H.E. (2014). The tyranny of love: love addiction - an anthropologist's view. Dalam: K.P. Rosenberg dan L.C. Feder (eds), Behavioral Addictions: Criteria, Evidence, and Treatment. London: Academic Press, pp. 237-266.

Frankfurt, H. G. (1971). Freedom of the Will and the Concept of a Person. The Journal of Philosophy, 68(1), 5-20.

Fromm, E. (2000). The art of loving: The centennial edition. A\&C Black.

Gailliot, M. T., Baumeister, R. F., DeWall, C. N., Maner, J. K., Plant, E. A., Tice, D. M., \& Schmeichel, B. J. (2007). Self-control relies on glucose as a limited energy source: willpower is more than a metaphor. Journal of personality and social psychology, 92(2), 325.

Griffin-Shelley, E. (1997). Sex and love: Addiction, treatment, and recovery. Greenwood Publishing Group.

Hatfield, E., Bensman, L., \& Rapson, R. L. (2011). A brief history of social scientists' attempts to measure passionate love. Journal of Social and Personal Relationships,29(2), 143-164. doi:10.1177/0265407511431055

Hatfield, E., Schmitz, E., Cornelius, J., \& Rapson, R. L. (1988). Passionate love: How early does it begin? Journal of Psychology \& Human Sexuality, 1(1), 35-51.
Hatfield, E., \& Sprecher, S. (1986). Measuring passionate love in intimate relationships. Journal of Adolescence,9(4), 383-410. doi:10.1016/s0140-1971(86)80043-4

Hatfield, E., \& Sprecher, S. (2010). The passionate love scale. Dalam T. D. Fisher, C. M. Davis, W. L.Yaber, \& S L. Davis (Eds.), Handbook of sexuality-related measures: A compendium (3rd Ed.) (pp. 469-472). Thousand Oaks, CA: Taylor \& Francis

Hatfield, E., \& Rapson, R. L. (1993). Love, sex, and intimacy: Their psychology, biology, and history. HarperCollins College Publishers.

Hayes, A.F. (2013) Introduction to mediation, moderation, and conditional process analysis: A regression-based approach. New York: The Guilford Press.

Hazan, C., \& Diamond, L. M. (2000). The place of attachment in human mating. Review of General Psychology, 4(2), 186.

Liebowitz, M. R. (1983). The chemistry of love. Little, Brown.

Li, Y. J., Kenrick, D. T., Griskevicius, V., \& Neuberg, S. L. (2012). Economic decision biases and fundamental motivations: How mating and self-protection alter loss aversion. Journal of Personality and Social Psychology, 102(3), 550-561. doi:10.1037/a0025844

Meloy, J. R. (1998). The psychology of stalking. The psychology of stalking: Clinical and forensic perspectives, 1-23.

Nunnally, J. C., \& Bernstein, I. H. (1994). The assessment of reliability. Psychometric theory, 3(1), 248-292.

Paulhus, D. L., \& Carey, J. M. (2011). The FAD-Plus: Measuring Lay Beliefs Regarding Free Will and Related Constructs. Journal of Personality Assessment, 93(1) doi:10.1080/00223891.2010.528483

Phillips, A. T., \& Wellman, H. M. (2005). Infants' understanding of object-directed action. Cognition, 98(2),137-155.

Sprecher, S., Aron, A., Hatfield, E., Cortese, A., Potapova, E., \& Levitskaya, A. (1994). Love: American style, Russian style, and Japanese style. Personal Relationships, 1(4), 349-369.

Stanton, S. C., Campbell, L., \& Loving, T. J. (2014). Energized by love: Thinking about romantic relationships increase positive affect and blood glucose levels. Psychophysiology, 51(10), 990-995.

Watson, G. (1987). Free action and free will. Mind, 96(382), 145-172. 